\title{
Opening Markets for Poor Countries: Are We There Yet?
}

\section{Kimberly Ann Elliott}

\begin{abstract}
Despite six decades of trade liberalization, trade policies in rich countries still discriminate against the exports of the world's poorest countries. Preferential market access programs were designed to spur larger and more diversified exports from developing countries, but product exclusions and burdensome rules undermined their usefulness, especially for the poorer countries. Most rich countries have made reforms since the UN Millennium Declaration in 2000 called for duty-free, quota-free market access for the least-developed countries. After the World Trade Organization ministerial communiqué called upon developing countries "in a position to do so" to also provide such access, key countries have moved toward that goal. But much remains to be done to achieve the goal of meaningful market access for the poorest countries, including reformed rules of origin that facilitate rather than inhibit trade.
\end{abstract}




\title{
Opening Markets for Poor Countries: Are We There Yet?
}

\author{
Kimberly Ann Elliott \\ Center for Global Development
}

October 2009

I would like to thank the Hewlett Foundation for supporting this research, Julia Sekkel for research assistance, and Nancy Birdsall and other colleagues at the Center for Global Development for encouragement and many helpful discussions on issues in the paper. Gary Hufbauer, Peter Kleen, Sheila Page, Arvind Subramanian, and Ann Weston provided thoughtful comments for which I am extremely grateful. Any remaining errors are mine and the views expressed are also mine alone and do not reflect the views of the Center's board, management, or staff.

Kimberly Ann Elliott. 2009. "Opening Markets for Poor Countries: Are We There Yet?” CGD Working Paper 184. Washington, D.C.: Center for Global Development. http://www.cgdev.org/content/publications/detail/1422923

Center for Global Development 1800 Massachusetts Ave., NW Washington, DC 20036

202.416.4000

(f) 202.416 .4050

www.cgdev.org
The Center for Global Development is an independent, nonprofit policy research organization dedicated to reducing global poverty and inequality and to making globalization work for the poor. Use and dissemination of this Working Paper is encouraged; however, reproduced copies may not be used for commercial purposes. Further usage is permitted under the terms of the Creative Commons License.

The views expressed in this paper are those of the author and should not be attributed to the board of directors or funders of the Center for Global Development. 


\section{Opening Markets for Poor Countries: Are We There Yet?}

\section{Kimberly Ann Elliott}

Trade is about expanding opportunities - for consumers to be able to choose from a wider variety goods at lower prices and for firms to grow by becoming more productive and accessing broader markets. For the poorest countries in the world, however, those opportunities have been shrinking. In 2000, the share of the least-developed countries (LDCs) in world trade was under one percent and it was one-third of what it had been for those same countries in 1970, when it was just under 2 percent. Exports from these countries also remain highly concentrated in a few sectors, exposing them to increased volatility and external shocks. There are many reasons for this, including corruption, conflict, and bad economic policies in some developing countries. But it is also the result of rich-country policies that discriminate against exports from poor countries in all too many cases.

The United Nations formula for designating countries as least-developed when they are small, poor, and vulnerable to external shocks currently applies to 49 countries accounting for less than one percent of world trade. And, yet, no rich country has fully opened its market to these poor countries. The European Union (EU) claims to have done this with the "Everything But Arms" (EBA) program and, going into the Pittsburgh Summit of the G-20, it called on the other leaders to replicate the EBA. But what EU leaders did not mention is that the program's rules of origin inhibit LDC exports, particularly of apparel. Canada comes the closest to providing meaningful duty-free, quota-free access for LDCs, but it continues to protect sensitive agricultural products. The United States provides broad access for most of sub-Saharan Africa, but it also maintains protection for domestic producers of sugar and other sensitive agricultural products, and it effectively ignores a number of Asian LDCs. Japan also protects certain agricultural and fishery producers from those far poorer than them, and South Korea holds back because it wants to avoid classification as a developed country under international trade rules.

Thus, a major reason that preference programs have not done more to help developing countries is that many of them retain the regressive features that mar rich-country trade policy more broadly. Overall, average tariffs in the rich countries are in the low single digits, but the highest remaining tariffs are generally in sectors where poor countries have a comparative advantageagricultural products, textiles and apparel, footwear, and other light manufactures. And these products are also often excluded from preference programs. Even where nominal market access is more open, rules of origin and other administrative obstacles prevent some countries from taking advantage of preferences, as with the EBA. Finally, uncertainty surrounding the stability of the commitments under these programs, because they are unilateral and must be renewed periodically, deters investment in potential export sectors. In addition, trade among developing countries is of growing importance and it is only recently that some of the more advanced of those countries have introduced or announced plans to expand duty-free programs for LDCs. 
So the potential for improved preference programs to spur exports remains, especially for poorer countries, whose exports remain concentrated in high-tariff sectors. The economic and political environment in mid-2009 also lends urgency to the preference reform agenda for these countries. Efforts in Summer 2008 to bring the Doha Round of global trade negotiations to a conclusion collapsed and the Round is unlikely to be concluded for some time. In the interim, negotiation of bilateral and regional trade agreements could accelerate, thereby increasing discrimination against the smallest and poorest, countries that are often excluded from commercially significant agreements. In 2009, poor countries were also being hammered by an economic crisis that they had no role in creating.

Expanded preferential access for the LDCs is also on the policy agenda today because the rich countries are politically committed to providing it at both the United Nations and the World Trade Organization (WTO). The eighth of the UN Millennium Development Goals focuses on the role that the rich countries should play in helping developing countries to achieve the other seven goals to reduce poverty and improve health, education, and other outcomes for the poor. This goal extends to trade as well as aid and debt relief and, among other things, calls on rich countries to provide "duty-free, quota-free" access for LDCs. ${ }^{1}$ The commitment was affirmed in 2005 at the WTO's ministerial meeting in Hong Kong, where the communiqué called for DFQF access for the LDCs by 2008, or the end of the Doha Round, which, at the time, was expected to occur sooner. Unfortunately, U.S. negotiators insisted on limiting the access to 97 percent of products, an exemption that would rob the proposal of most of its benefit. ${ }^{2}$ On a more positive note, the Hong Kong communiqué also called on emerging markets "in a position to do so," to provide DFQF access. The communiqué also called on preference givers to "ensure that preferential rules of origin applicable to imports from LDCs are transparent and simple, and contribute to facilitating market access.",3

The paper begins by addressing the rationale for focusing on preference reform for the poorest countries, which lies in the regressive nature of trade policies in many rich countries and the proliferation of regional trade agreements that add to the discrimination against LDCs. The next section assesses the major preference programs and asks, who is leading in the efforts to provide nominally full market access to the exports of the poorest countries? The paper then turns to rules of origin, which all too often render access meaningless in practice, including in the European Union and associated countries. This is followed by an overall assessment of rich-country programs, including elements related to real as well as nominal access, and then a section on improving preference programs through expanded geographic reach.

\footnotetext{
${ }^{1}$ There are 49 United Nations-designated least-developed countries with per capita incomes below $\$ 750$ and with other features of vulnerability, such as small size or volatile exports (www.un.org/specialrep/ohrlls/ldc/ldc\%20criteria.htm). Cape Verde recently "graduated" from LDC status.

${ }^{2}$ Antoine Bouet, Simon Mevel and David Orden, "Two Opportunities to Deliver on the Doha Development Pledge." IFPRI Research Brief No. 6, 2006; see also Valdete Berisha-Krasniqi et. al. "The Development Promise: Can the Doha Development Agenda Deliver for Least-Developed Countries?” IFPRI Briefing note No. 14, 2008.

${ }^{3}$ The DFQF market access commitment may be found in Annex F of the communiqué at http://www.wto.org/english/theWTO_e/minist_e/min05_e/final_annex_e.htm.
} 
The paper concludes with recommendations for preference reform that includes rich countries moving as soon as possible to:

- $\quad$ provide 100 percent duty-free, quota-free access for the exports of all least-developed countries;

- $\quad$ simplify rules of origin to ensure that the removal of border measures translates in genuine access; and,

- make their programs permanent to reduce uncertainty and encourage investment.

Emerging economies should implement similar policies, perhaps phasing in 100 percent access over a longer period. Other important recommendations for reform, including better coordination of aid for trade and capacity-building assistance to address supply-side challenges, will be discussed in the forthcoming report of the Global Trade Preference Program Working Group, which is scheduled for release by the Center for Global Development in early $2010 .^{4}$

\section{Do Unilateral Preferences Still Matter?}

The Generalized System of Preferences was launched in the 1970s as a mechanism for developing countries to expand and diversify their exports, with the aim of stimulating growth and reducing poverty. Under these unilateral trade preference programs, rich countries grant additional market access for the exports of developing countries and they have been strikingly successful in boosting exports in some cases. But there are a number of weaknesses in these programs that undermine their usefulness.

Preference erosion is a fact of life for trade preference program beneficiaries. The difference between the preferential tariff level (often zero) and the tariff level applied to other countriesthe preference margin - is shrinking for two major reasons. First, non-preferential tariffs in rich countries, so-called "most-favored-nation" tariffs (MFN), are in the low single digits as a result of 60 years of multilateral negotiation. Second, the MFN rate applies to fewer and fewer countries because of the proliferation of regional trade agreements in recent years. ${ }^{5}$

But on both scores, there is room to improve preferential access for the poorest. Although the overall average tariff in rich countries is in the low single digits, there are many tariffs that are well above the average and they tend to be in sectors that disproportionately affect LDCs. And

\footnotetext{
${ }^{4}$ Additional information about the working group may be found at http://www.cgdev.org/section/initiatives/_active/reformingtradepreferences/global_trade_preference_reform. There is also an informal Washington, DC-based coalition working on broader reforms in all U.S. preference programs. For a brief summary of the U.S. coalition recommendations, clink on the link to the joint letters in this blog posting: http://blogs.cgdev.org/globaldevelopment/2009/04/continuing-efforts-to-make-trade-work-for-development.php. ${ }_{5}^{5}$ Preference erosion can also occur as the result of unilateral reforms, such as the EU response to a WTO dispute settlement panel against it that resulted in the support price for sugar be reduced by a third, which, in turn, reduced the value of quota access held by beneficiaries of the EU's ACP program or, now, EBA.
} 
when it comes to commercially significant regional and bilateral trade agreements, LDCs are also typically left out, either because their markets too small to be of interest, or they opt out because they fear having domestic firms and farmers swamped by imports from more developed economies. Deeper unilateral preferences can thus help to mitigate the discrimination that LDCs face from the proliferation of regional trade agreements.

The regressive pattern in trade policies is illustrated in table 1, which shows average tariffs by sector, as well as the distribution of tariff peaks across the Quad countries. The concentration of tariff peaks in agriculture and low-wage manufactures hits low-income countries particularly hard because nearly half of their non-oil exports are in these sectors (based on 2006 data). ${ }^{6}$ Low middle-income countries are also relatively dependent on agricultural exports and low-wage manufactures, including textiles, clothing, and footwear, (table 2).

This combination of export concentration in poor countries and market access barrier concentration in rich countries translates into a regressive tax, hitting the poor both globally and at home, since the poor, even in rich countries, spend a larger share of their income on food, clothing, and footwear, than do the rich. ${ }^{7}$ The impact of these patterns on poor countries is only partially mitigated by trade preference programs, particularly in the United States. More than three-quarters of U.S. non-oil imports from LDCs are in the apparel sector, mostly from Bangladesh and Cambodia, and 83 percent of those imports receive no preferential treatment.

As a result of high U.S. tariffs and a high concentration of their exports in the apparel sector, Cambodia and Bangladesh paid a higher overall average tariff than any other American trading partner (excluding non-independent territories). The value of the import taxes levied on exports from these poor countries - nearly $\$ 1$ billion in 2008 - was roughly the same as the value of duties collected on a far higher value of exports originating in the United Kingdom and France. In 2006, the combined $\$ 800$ million tariff bill for Cambodian and Bangladeshi exports was seven times larger than the U.S. aid these countries received. Mongolia, Sri Lanka, and Laos, all with annual average per capita incomes in 2007 of $\$ 1,000$ or less, are just behind, with average tariffs on their exports of 10 percent or more (table 3 ).

Reciprocal preferential trade agreements are also a challenge for LDCs. Figure 1 shows all such agreements to which LDCs are a party. Although some are in agreements with neighbors that fall into the upper middle-income bracket, and a few in Asia are members of agreements that include the large and rapidly-growing emerging markets of that region, none is currently involved with a

\footnotetext{
${ }^{6}$ World Trade Organization, "Market Access for Products and Services of Export Interest to Least-Developed Countries," Note by the Secretariat, WT/COMTD/LDC/W/42/Rev. 1, 26 February 2009, Geneva. In the table, the relatively low average tariff for U.S. agricultural imports masks the highly restrictive tariff-rate quotas on certain products of interest to African LDCs including sugar, tobacco, and peanuts.

${ }^{7}$ William R. Cline documented the regressive nature for American consumers of barriers to textile and apparel imports in The Future of World Trade in Textiles and Apparel, revised edition, Washington: Institute for International Economics, 1990. The Uruguay Round of multilateral trade negotiations subsequently lowered some of the barriers to textiles and apparel trade, but the general pattern of relatively barriers in this sector, and higher costs for consumers, remains.
} 
reciprocal preferential agreement with a rich country. The EU is currently in the process of trying to negotiate economic partnership agreements with the countries, including a number of LDCs, that were previously eligible for unilateral preferences under the Cotonou arrangement. Those agreements have been controversial, however, and, except for the Caribbean, only interim agreements have been signed thus far. ${ }^{8}$ The interim agreements generally provide duty-free, quota-free access for the developing-country partner, while delaying the implementation of reciprocal market-opening and commitments in other areas. But these agreements have been criticized for complicating the regional integration that is occurring in sub-Saharan Africa and in forcing poor countries to adopt rules in areas such as intellectual property that may not be in their interest at current levels of development.

\section{Who's Setting the Pace in Providing Access for the Poor?}

Since 2000, the rich countries have made important progress toward the goal of providing DFQF market access for LDCs (table 4). The European Union introduced the Everything But Arms (EBA) program for LDCs in 2001, the same year that the United States implemented the African Growth and Opportunity Act (AGOA). Over the next couple of years, Australia, New Zealand, Iceland, and Norway announced similar programs, though Iceland did not go to 100 percent product coverage as the others in that group did. In subsequent years, Switzerland and Turkey adopted programs modeled, more or less, on the EU's EBA program, while Japan and South Korea expanded the list of DFQF-eligible products for LDCs to 98 percent and 75 percent, respectively. A few countries went beyond the norm in various ways. Norway extended DFQF access beyond LDCs to other low-income countries with populations below 75 million (the threshold for determining LDC status), while Switzerland extended it to a handful of "highly indebted poor countries."

While Europe, Australia, and New Zealand, have thus reached 100 percent nominal DFQF access for LDCs, Canada's 2003 reform is the more intriguing. In addition to expanding the list of duty-free, quota-free imports from LDCs to 99 percent (excluding only dairy, eggs, and poultry, supplies of which are managed to prop up the price), Canada also modified its rules of origin, including for apparel. The subsequent trade response in Canada is striking and the impact of the Canadian reform in comparison to that of others that did not change rules of origin is addressed in the next section.

Like the other Quad countries, the United States has a broader list of eligible products under its Generalized System of Preferences that is available to LDCs. But even the expanded list excludes a number of "import-sensitive" products, including many agricultural products and

\footnotetext{
${ }^{8}$ For an analysis of the potential negative effects of the EU economic partnership agreements on fiscal revenues and trade diversion in developing-country partners, see Antoine Bouet, David Laborde, and Simon Mevel, "Searching for an Alternative to Economic Partnership Agreements" IFPRI Research brief No. 10, 2007.
} 
most labor-intensive goods that are important to developing countries. Compared to the 98 percent or better access that the rest of the Quad, and most other rich countries, provide to LDCs, the U.S. GSP program provides duty-free, quota-free access on only a bit over 80 percent of the items in its tariff schedule (table 5).

The U.S. government is more generous in regional programs for the Caribbean, Andean, and sub-Saharan African countries, each of which has its own country and product eligibility conditions and rules of origin. There are no LDCs in the Andean region, but the Caribbean Basin Trade Partnership Act covers Haiti, with expanded access under the HOPE (Haitian Hemispheric Opportunity through Partnership Encouragement) Act, and AGOA is potentially available to 34 sub-Saharan African LDCs. Under the HOPE Act and AGOA, eligible LDCs (and in the latter case other "lesser developed beneficiary countries") receive duty-free treatment on roughly 91 percent and 98 percent of U.S. tariff lines, respectively.

Even under the most generous programs, however, U.S. market access is not quota-free. Tariffrate quotas are retained for sensitive agricultural products, most notably sugar, and there is a ceiling on the volume of clothing that can be exported to the U.S. market without having to meet a rule of origin that requires the use of U.S. fabrics. As of the beginning of 2009, only 18 subSaharan LDCs were designated as eligible to export clothing to the United States under a special rule allowing them to use fabric from any source, up to the ceiling of 3.5 percent of total U.S. apparel imports. ${ }^{9}$ As of the end of 2008 , the ceiling was not binding and just five countries accounted for 90 percent of African clothing exports to the United States under AGOA. The HOPE Act (and subsequent revisions) also provides better-than-average access to the U.S. market for Haiti, but it is not as broad as under AGOA, and the rules of origin are complex. For other LDCs, however, the U.S. tariff structure remains highly regressive.

\section{The Potential Value of Nominal Access, and the Reality of Access with Rules of Origin}

Removal of border measures provides nominal access but does not by itself guarantee actual access. Simulations using partial equilibrium methodologies suggest that 100 percent duty-free, quota-free market access in the rich countries could increase LDC exports by 11 percent to 17 percent, assuming full utilization. Estimates of the impact of moving from 97 percent to 100 percent of tariff lines as part of a feasible Doha Round package suggest that the welfare gains for LDCs would increase seven-fold, from $\$ 1$ billion to $\$ 7$ billion. ${ }^{10}$ There is also evidence from

\footnotetext{
${ }^{9}$ In addition, eight other sub-Saharan African countries can export apparel to the United States under the special apparel rule because U.S. rules set a higher income threshold than for the UN-designated LDCs and it also designated Botswana and Mauritius as eligible, even though they are well above even that threshold.

${ }^{10}$ On the impact of 97 percent versus 100 percent coverage in the context of a Doha Round, see Bouet, Mevel, and Orden op cit. Antoine Bouet, David Laborde, Elisa Dienesch, and Kimberly A. Elliott (forthcoming) will examine additional scenarios involving different combinations of product and country coverage.
} 
recent reforms that confirms that fewer exclusions, when coupled with less restrictive ROOs, have tangible effects on exports.

A World Bank paper written prior to the reforms that have taken place in most rich countries estimated that reducing tariffs to zero in the Quad countries would boost LDC exports by $\$ 2.5$ billion, just over 10 percent of the $\$ 23$ billion in LDC exports to the world at the time. Although dated, the paper is still useful because it breaks out the potential gain in each of the Quad countries, as well as estimating the net increase in imports in those countries. According to this analysis, most of the potential gains from reform were in Canada, followed by the United States and, further back, Japan. Projected gains in the EU market were small because most LDCs were already getting close to duty-free treatment under the Cotonou Agreement for African, Caribbean, and Pacific countries. ${ }^{11}$

In a more recent paper, David Laborde compared the outcomes from 97 percent duty-free, quotafree product coverage by rich countries other than the EU to that from 100 percent coverage in the context of a Doha Round agreement. ${ }^{12}$ The 97 percent market access threshold helps to reduce the preference erosion that many LDCs would otherwise suffer from multilateral liberalization, but it provides virtually no additional export gains. Moving to 100 percent coverage boosts the potential gains from just $\$ 70$ million to over $\$ 2$ billion, around 17 percent of the exports of the LDCs covered, which is limited to 32 WTO members. If the emerging markets of Brazil, China, India, South Korea, and Mexico also provided 100 percent DFQF access, the export gains could increase by another several billion dollars. ${ }^{13}$

Actual trade data, however, suggest that these estimates may be exaggerated because they cannot easily account for rules of origin. These rules are nominally intended to protect against the possibility of trade deflection, where goods produced in a non-beneficiary country are simply transshipped through beneficiary countries in order to qualify for preferential market access, and with no value added locally. The basic criterion is usually that any imported inputs must be "substantially transformed" in the beneficiary country to be eligible for preferences, but countries and regions define that phrase in a variety of ways with varying degrees of transparency and complexity. Some require a minimum share of final value that must be added locally, others a change in tariff heading (which will be more restrictive the more aggregated is the product category), and some specify technical processes to define what "substantial transformation" means. ${ }^{14}$

\footnotetext{
${ }^{11}$ Bernard Hoekman, Francis Ng and Marcelo Olarreaga, "Eliminating Excessive Tariffs on Exports of Least Developed Countries", World Bank Policy Research Working Paper No. 2604, 2001.

${ }^{12}$ The European Union is excluded because it had already provided 100 percent DFQF under the EBA.

${ }^{13}$ David Laborde, "Looking for a meaningful Duty Free Quota Free Market Access Initiative in the Doha Development Agenda", ICTSD Issue Paper No.4, 2008.

${ }^{14}$ Antoni Estevadeordal and Kati Suominen (in Gatekeepers of Global Commerce: Rules of Origin and International Economic Integration, Washington: Inter-American Development Bank, 2008) provide a comprehensive description and analysis of the different types of rules of origin in regional trade agreements around the world.
} 
The latter approach is common in the case of apparel, which is an import-sensitive product in many rich countries, but also an important export for poor countries. For example, the general U.S. rule for apparel in most of its trade agreements and preference programs (if they include apparel at all) requires that it undergo a triple transformation to be eligible - that it is, the clothing item must be produced from fabric that is produced locally or in the United States using either local or U.S. yarn, and then cut and assembled in the beneficiary country. The European Union has a rule based on double transformation, meaning that the yarn can be imported, but the fabric cannot (again, unless it is from the EU, or a few other designated trade partners). ${ }^{15}$

Some defend such rules as designed to promote the objective of creating or promoting upstream industries, to encourage backward linkages, in this case to textiles. As Stevens and Kennan (2004, p. 7) note, however, the impact of rules of origin is asymmetric: setting them too high can eliminate the benefits of preferences entirely, while setting them too low may reduce the benefit, by not developing backward linkages, but it will not eliminate the benefit. They conclude:

Since it will always be very difficult to set the rules so that they are 'just right', the implication is that preference-givers should always err on the side of cautious liberality. (ibid.)

In practice, many rules of origin are set at levels that appear to be unrealistic for lower-income exporters. Where value-added thresholds are used, they often require that half or more of the value of the product must have local origins. But, with globalization, supply chains have become increasingly fragmented and these rules increasingly difficult to meet, especially in smaller, poorer countries with low capital investment and few economies of scale. A study by the Overseas Development Institute found that, of 34 broad product categories analyzed in 7 lowincome countries, local value-added was less than 40 percent in $26 .^{16}$

If harmonization of rules of origin by the rich countries is not possible, and it seems unlikely given the wide variety of rules and the political pressures that influenced their development, "extended cumulation" is a reform that might be easier to adopt and still have positive effects for poor countries. ${ }^{17}$ For example, Canada requires that 40 percent of clothing items must be "locally" produced to be eligible for duty-free, quota-free access, a threshold that the ODC suggests could be difficult for many low and low middle-income countries to meet. ${ }^{18}$ But LDCs can cumulate imported inputs from Canada or any other developing country beneficiary of Canada's GSP program, including China, and still have the item recognized as originating in the

\footnotetext{
${ }^{15}$ In both cases, there are variations, with regional fabric allowed under some circumstances and exceptions that allow apparel using third-country fabric to remain eligible up to designated ceilings in some programs, a discussed below.

${ }^{16}$ Overseas Development Institute, "Creating Development Friendly Rules of Origin in the EU”, Final Report, 2006, p. 25.

${ }^{17}$ Jeremy T. Harris, "Rules of Origin for Development: from GSP to Global Trade" Inter-American Development Bank, INT Working paper 03, 2nd quarter, 2008.

${ }^{18}$ Overseas Development Institute op cit., pp. 44-45.
} 
LDC. The EBA uses the restrictive double transformation rule for apparel and allows only limited regional cumulation.

While the data shown in figure 2 are not definitive, they are suggestive of the impact of these different rules of origin. Figure 2 shows the share of non-oil imports from LDCs in rich countries that expanded access in the early 2000s. For the United States and EU, only imports from AGOA-eligible (not all of them LDCs) and non-ACP LDCs, respectively, are shown This is because one would not expect to see changes in trends in market shares for LDCs overall in these markets because the United States expanded access only for certain countries in sub-Saharan Africa, while ACP countries eligible for the Cotonou Agreement had nearly full access to the EU market prior to adoption of the EBA. ${ }^{19}$

Figure 2 offers support for the conclusion that rules of origin matter. Using this measure, the only market shares that show any noticeable change in trends after preference program reforms are Canada and the United States, the only two countries that also modified their rules of origin to facilitate imports of apparel. Canada both lowered the value-added threshold for LDCs (from 60 percent previously) and allowed them to cumulate inputs from all developing country beneficiaries, not just other LDCs. And the U.S. AGOA program contains an exception from the normal triple transformation rules for apparel for "lesser-developed beneficiary countries" that allows them to source fabric anywhere - up to a ceiling. By contrast, Norway and Switzerland (not shown because its reform occurred only in 2007) harmonized their rules of origin with the EU, meaning they all have rules of origin for apparel requiring double transformation with only limited regional cumulation.

More sophisticated empirical analyses also find limited effects of the EBA program and far stronger effects of the Canada program for LDCs, and for the U.S. AGOA program for apparel. Anson et al., for example, find that the Canadian reform led to more countries benefiting from preferential access, increased imports from existing beneficiaries, and an expanded range of imports from beneficiaries. ${ }^{20}$ Frazer and van Biesebroeck estimate that AGOA increased African apparel exports to the United States by as much as 50 percent. Though they also estimate that AGOA continued to have a strong and positive impact on apparel exports after the end of the quota system under the Multi-Fiber Arrangement, the decline in the value of those exports since

\footnotetext{
${ }^{19}$ In recent years, the U.S. Congress also expanded access, and added flexibility to the rules of origin, for apparel exports from Haiti. This experience will be addressed in detail in a forthcoming case study.

${ }^{20}$ On the impact of the Canadian reform, see Jose Anson, Marc Bacchetta and, Matthias Helble, "Using Preferences to Promote LDC Exports: A Canadian Success Story?" Journal of World Trade 43.2: 285-315, 2009; on the limitations of EU preferences, Fabien Candau and Sébastien Jean (forthcoming); on AGOA and the EBA, see Christopher Stevens and Jane Kennan, "Comparative Study of G8 Preferential Access Schemes for Africa", Institute of Development Studies, 2004; and Paul Brenton and Caglar Ozden, "Trade Preferences for Apparel and the Role of Rules of Origin - the Case of Africa" in Bernard Hoekman, Will Martin and Carlos A. Primo Braga (edit.), Preference Erosion: Measurement and Policy Response, Washington: The World Bank, 2009.
} 
2005 underscores the limitations of preferences to sustainably boost exports if fundamental competitiveness is not also addressed. ${ }^{21}$

Overall, estimates of the costs of meeting rules of origin are in the range of 3-4 percent. ${ }^{22}$ Given that most MFN tariffs in rich countries fall in or below this range, many studies find that countries often do not bother to claim benefits for exports where the preference margin is that low because the administrative costs of doing so are higher than the value of the preference. In the case of apparel and some other product-specific rules, there are estimates that the tariff equivalent of restrictive rules is in the range of $15-20$ percent. $^{23}$ There is also evidence for rules having a substantial impact in the different patterns of trade in apparel between LDCs and the United States and European Union. The two chapters in the tariff system that cover most apparel are 61, which includes knitted items, and 62, which covers woven garments. In the former category are items, such as sweaters, that are "knit-to-shape," thus meeting the EU rule, which requires that only the yarn for knit apparel, not fabric, can be imported. This technology is far simpler and the capital requirements less than for woven fabrics (Stevens and Kennan 2004, pp 111-112). In contrast, the U.S. AGOA rule allows "lesser-developed beneficiary countries" (a broader category than LDCs) to perform a "single transformation," assembling fabric that may be sourced anywhere (subject to a cap) into clothing. The United States used a similar rule prior to AGOA, when the MFA quotas were in place and it granted no tariff preferences on apparel.

These variations in access and rules result in trade patterns that are consistent with what one would expect to see if rules of origin have a significant impact on exports. Thus, Demidova et al. find that, even after the EU adopted the EBA, Bangladesh was able to export woven apparel to the United States despite an average tariff between 15 percent and 20 percent, while its exports to the EU were concentrated in the knitwear sector, where the rule of origin was easier to meet. ${ }^{24}$ A similar pattern can be seen with respect to African apparel exports (figure 4). Sub-Saharan African countries increased exports to the United States of both knitted and woven apparel, while exports to the EU of woven apparel show no response to introduction of the EBA in 2001.

In sum, there is both academic analysis and real-world evidence that rules of origin can thwart the utilization of trade preferences. Given the heterogeneity of developing countries, the fragmentation of global supply chains, and the highly varied approaches by the major preferencegiving countries, adoption of simplified and harmonized rules of origin that would facilitate trade would seem to be both politically and substantively difficult. Mutual recognition of one another's rules across the rich countries is one option; that is, preference givers would agree that an import that qualifies for preferential treatment in one market would be accepted as eligible in any other.

\footnotetext{
${ }^{21}$ Garth Frazer and Johannes Van Biesebroeck, 2007, "Trade Growth under the African Growth Opportunity Act" NBER Working Paper 13222.

${ }^{22}$ Hoekman, Martin, and Braga op cit.

${ }^{23}$ See Olivier Cadot and Jaime de Melo,"Why OECD Countries should Reform Rules of Origin," Institut de Macroeconomie Appliqueé, Université de Lausanne, 2007.

${ }^{24}$ Svetlana Demidova, Hiau Looi Kee, and Kala Krishna, "Do trade policy differences induce sorting? Theory and evidence from Bangladesh apparel exporters," NBER Working Paper 12725, 2006.
} 
But this would require cooperation and trust across customs agencies that could be difficult to achieve and it could also run into trouble if there are differences in which beneficiaries preference givers recognize as eligible.

Extended cumulation, which allows inputs to be sourced from a broad range of countries and still be eligible for preferences, would provide extensive flexibility for beneficiary countries and could be implemented unilaterally. It could also encourage South-South liberalization as preference beneficiaries seek to improve competitiveness by further lowering the costs of the inputs they are now allowed to import from other developing countries for cumulation purposes. The option that would provide the broadest flexibility for LDCs under duty-free, quota-free programs, and do the most to encourage South-South trade, would allow for cumulation of inputs from other LDCs and developing countries, as well as any countries with whom the preferencegiving country has free trade agreements. ${ }^{25}$ This version would address an anomaly that has arisen under Canada's program for LDCs, whereby Haiti still faces high tariffs on many of its clothing exports because they incorporate fabric from the United States-fabric that would enter Canada duty-free under NAFTA if imported directly from the United States. ${ }^{26}$

Finally, another facet of these programs that undermines their development effectiveness is unpredictability due to frequent renewals or arbitrary conditions for eligibility. Japan and Canada authorize their programs for a decade at a time. The EU's regular GSP program is renewed every three years, without the political drama that often occurs in the United States, while the EBA has no termination date. South Korea's program was created by presidential decree, which can be reversed at any time. The United States has different terms for different programs and, after lengthy terms early in its GSP history, the program has been renewed eight times since 1993, usually only for one to two years and in several cases the U.S. GSP program lapsed for from one to fourteen months at a time. ${ }^{27}$ The uncertainty created by frequent renewals undercuts incentives to invest to take advantage of the program and, among other things, could undermine export diversification goals.

\section{An Overall Assessment of OECD Preferences for LDCs}

Summing up the evidence on both nominal and real market access, and focusing on the top five high-income traders, which account for over half of LDC merchandise exports, Canada is clearly in the lead, while South Korea lags badly. If the most generous U.S. program is assessed separately, then AGOA looks at least as good as the EU's Everything But Arms, perhaps better if rules of origin are weighted more heavily than other provisions of the programs. Japan's program

\footnotetext{
${ }^{25}$ See Harris op. cit.

${ }^{26}$ Ann Weston of the North-South Institute and a member of the CGD Working Group on Global Trade Preference Reform pointed this out in a letter to the editor of the Ottawa Citizen on September 19, 2009.

${ }^{27}$ See Vivian C. Jones, "Generalized System of Preferences: Background and Renewal Debate", Congressional Research Service, Order code RL33663, June 16, 2008.
} 
for LDCs is in the same neighborhood, while the U.S. GSP for LDCs, which covers those in Asia, is well behind, but still ahead of South Korea. Table 6 summarizes the key features of these programs as they apply to the LDCs and ranks them, as well as assigning an overall score for each program (generated by simply summing the ranks on each component).

Among these major economies, only the EU will provide nominal 100 percent duty-free, quotafree access for the products of LDCs by the end of 2009 when it is fully implemented. ${ }^{28}$ Canada restricts exports of dairy, eggs, and poultry products, but has rules of origin that are easier for poor countries to meet than those set by the EU. Japan offers better access to more LDCs than the United States, but with more restrictive rules of origin on most products, though it has a relatively liberal, single transformation, rule of origin for woven apparel. In contrast, Korea, which clings to developing country status in the WTO, has no GSP program and offers the most limited benefits to LDCs.

The overall conclusion that the United States lags in its overall trade policy for poor countries seems inconsistent with the Center for Global Development's Commitment to Development Index, where U.S. trade policy usually comes out just behind Australia and New Zealand, and just ahead of Canada. ${ }^{29}$ The high-income EU countries follow somewhat further behind, while Switzerland, Norway and Japan fall clearly to the bottom of the ranking, well behind the EU. Korea, which was included in the index for the first time in 2009, comes in last, as it does here. In addition to the relatively poor U.S. showing here, the other surprises are Norway and Switzerland, which are similar to the EU in providing relatively more generous market access for the poorest countries, at least nominally.

But there are two key differences between the two measures. First, U.S. trade policy overall $i$ s generally more open than many other rich countries. Second, the Commitment to Development Index measures rich-country policies toward all developing countries, not just the leastdeveloped and the former tend to have more diversified export portfolios. But because of the concentration of remaining U.S. barriers in sectors, such as sugar and apparel, that are particularly important for LDC exporters, and the gaps in its preference programs, U.S. policy comes out worse on this measure of policy towards the poorest. Unlike Canada and the EU, which treat trade with the poorest countries as part of development policy, U.S. policymakers, particularly in Congress, have apparently not abandoned the traditional mercantilist bargaining framework, even for these countries.

\section{Expanding the Reach of Preferential Access for the Poorest: Who Are They? Who Else Should Grant It?}

\footnotetext{
${ }^{28}$ Australia, New Zealand, Norway, and Switzerland provide 100 percent duty-free, quota-free access for leastdeveloped countries, or close to it, but they are not analyzed separately because account for less than one percent of LDC exports.

${ }^{29}$ CDI webpage: http://www.cgdev.org/section/initiatives/_active/cdi/
} 
Expanding the geographic coverage of duty-free, quota-free access, both among preferencereceiving countries and preference-granting countries could boost the anti-poverty impact. Any threshold for providing DFQF is inevitably arbitrary and potentially creates losses for countries on just the other side of whatever line is drawn. But the UN-defined category of least-developed countries excludes a number of small, poor, and vulnerable countries and is the focus of the current debate primarily because it is the only distinction among developing countries that is recognized in the World Trade Organization. On the preference-giving side, Turkey, India, and China are among the emerging economies that offer duty-free programs with varying provisions for LDCs, while Brazil has announced plans to do so. This section surveys a number of options for extending the geographic reach of trade preferences for the poorest countries.

\section{Who should receive DFQF?}

Achieving the goal of duty-free, quota-free (DFQF) treatment for LDCs is at the core of this and other proposals for preference reform, but there a number of countries in Africa and elsewhere that are also small, poor, and vulnerable and not deemed as such under the UN formula for LDCs. There is sympathy for the idea of expanding DFQF eligibility, particularly in sub-Saharan Africa, but the idea also raises potential problems related to preference erosion for existing LDC beneficiaries and the possibility of a legal challenge in the WTO. Expansion to larger countries also raise issues of political feasibility in preference-giving countries because import-competing industries will feel more vulnerable.

Table 7 arrays developing countries by per capita income and size, illustrating some of the options for expanded eligibility. At the left are the UN-designated LDCs. In the middle are the countries that were in the World Bank's low-income category in 2007 and at the right, those countries that are below the low middle-income country threshold (\$3705). In the latter two cases, countries in those categories with total national incomes larger than $\$ 50$ billion are listed separately. In the low-income category, all of the "small" countries also have populations of less than 75 million, which is the figure used in the UN definition of an LDC and by Norway for its expanded DFQF eligibility list for low-income countries. (In addition, symbols are used to indicate countries that were ineligible for one or more U.S. preference programs as of the beginning of 2009 for political reasons, or countries that would otherwise be eligible but have signed free trade agreements with the United States. ${ }^{30}$ )

What is notable about the list of potential expanded eligibility countries is how many of them have suffered conflicts or other extreme disruptions, including as a result of the break-up of the Soviet bloc. Expanded eligibility along the lines suggested here would also give several countries in Africa and the Pacific an alternative to the economic partnership agreements that the EU is

\footnotetext{
${ }^{30}$ One recent exception is the FTA with Peru, where President Bush's proclamation implementing the agreement retained Peru's eligibility for the Andean preference program because it has a looser rule of origin for apparel.
} 
currently trying to negotiate as a replacement for the unilateral preferential arrangements under the Cotonou Agreement. As of mid-2009, only the Caribbean countries, other than Haiti, have signed a full EPA, while many LDCs have reverted to the EBA and others have signed "interim agreements" that allow them to retain preferential access to the EU market while postponing their own liberalization in most sectors for a number of years. Those negotiations have become controversial because they are viewed as forcing weak countries to accept provisions that they are not ready to implement, for example stronger protections for intellectual property, and because they are not always consistent with the direction of regional integration in sub-Saharan Africa. They would also threaten fiscal health in many countries because of the impact on tariff revenues, and estimates suggest that they would be more likely to result in welfare-lowering trade diversion than welfare-improving trade creation. ${ }^{31}$

But the broader the expansion of eligibility, the more likely that existing LDC beneficiaries will suffer losses from preference erosion. Adding the small low-income countries listed at the top of the middle column would likely have minimal impact on LDCs, while adding Vietnam and Pakistan could bring substantial benefits to those countries, but only at the expense of existing beneficiaries. It would also bring stronger objections from import-competing industries in preference-giving countries. These issues will be addressed more thoroughly in a forthcoming CGD working paper that uses a computable general equilibrium model to analyze the distribution of gains and losses from various DFQF scenarios. ${ }^{32}$

Finally, bringing in some low-income countries while excluding others as too large could raise additional legal questions in the WTO. Currently, the only distinction among developing countries that the WTO recognizes is LDCs and all others. The United States has had to request waivers for the regional programs that provide better-than-regular GSP for countries that are not LDCs. The EU waiver for African, Caribbean, and Pacific countries under its Cotonou Agreement for former colonies and related territories expired at the end of 2007 after the EU, in the face of opposition from a number of excluded developing countries, opted not to request a renewal. This suggests that any proposal to expand DFQF access beyond LDCs could run afoul of WTO rules on nondiscrimination and could be challenged.

There is, however, an appellate body ruling under the Dispute Settlement Understanding that opens the door to differential treatment for "similarly situated" developing countries, as long as the distinction is based on "objective criteria." That ruling was in response to an Indian challenge of the EU's GSP+ program, which provides additional benefits for countries meeting certain conditions for protecting worker rights and the environment. Initially that program also included benefits for countries combating drug trafficking and India won that part of the dispute because countries without drug-trafficking problems could not qualify. But the appellate body also overruled the initial panel ruling, which stuck to a very narrow definition of acceptable

\footnotetext{
${ }^{31}$ Bouet, Laborde, and Mevel op cit.

${ }^{32}$ See Bouet et al. op cit.
} 
differentiation among developing countries. In so doing, the appellate body introduced the possibility of using objective criteria applied to similarly situated countries that go beyond the LDCs.

\section{Who should provide DFQF access for LDCs, and how?}

The ministerial communiqué agreed to by WTO members in Hong Kong in 2005 reiterated the goal of rich countries eventually reaching DFQF access for the exports of LDCs and called on developing countries "in a position to do so" to strive for the same goal, albeit with more flexibility in implementation and with a longer period to achieve it. The larger emerging markets - China, India, and Brazil — are already moving in this direction and Turkey implemented the EBA program in conjunction with its customs union with the EU. The EU position paper for the G-20 summit in Pittsburgh in September called on all the leaders attending to adopt the EBA, though the gesture was undermined by the failure to simultaneously commit to reforming the rules of origin under that program.

The emerging economies already providing - or planning — some degree of DFQF access are to be applauded for moving ahead without being legally required to do so. But the growing importance of South-South trade also underscores the need to flesh out the meaning of the Hong Kong communiqué and create some guidelines for what a meaningful program would look like. Among the major emerging economies, three notified the WTO in recent years that they were implementing expanded preference programs for LDCs, as called for in the Hong Kong communiqué. In addition, Brazil announced plans to implement a program upon conclusion of the Doha Round of trade negotiations.

But all these programs have differing provisions that could undercut their utility for poor countries. For example, Turkey's customs union with the EU does not cover agriculture and, at least initially, its implementation of the EBA also did not include agriculture, a major gap for LDC exporters. ${ }^{33}$ Brazil's announced program would cover only the 32 WTO members that are LDCs, while China has different programs for Asian and African LDCs and does not offer access to countries that have diplomatic relations with Taiwan. India's program is open to all LDCs that register but, when phased in, it will provide duty-free access on only 85 percent of tariff lines and duty reductions on another 9 percent of tariff lines. China's product coverage for Africa initially covered less than 500 tariff lines, though these supposedly covered most LDC exports. But that limited list would block opportunities for trade creation and export diversification and China reportedly announced just prior to the G-20 meeting that it would open access on 95 percent of its tariff lines. Brazil has not yet specified the product coverage it will offer under its planned program.

\footnotetext{
${ }^{33}$ We are trying to confirm whether Turkey is phasing in 100 percent DFQF access on all products.
} 
This lacunae suggest some obvious recommendations for emerging economy programs:

- they should cover all LDCs,

- they should be implemented immediately, rather than waiting for the Doha Round to end,

- they should cover items, notably agriculture and apparel, that LDCs actually export, and

- they should have rules of origin that are flexible and easy for LDCs to meet.

But even with these gaps, at least China, India, and Turkey are offering some additional access for LDCs. While Brazil, should follow their example and not wait for Doha, other emerging economies have been silent.

The G-8 was expanded to the G-20 to give developing countries a voice on international economic issues that concern them, but with that leadership role comes responsibility. The other developing-country G-20 members that should step forward on DFQF access for LDCs include Mexico, Russia, Saudi Arabia, Indonesia, South Africa, and Argentina. In addition, Taiwan, Malaysia, the United Arab Emirates, and Thailand were major traders, accounting for more than 1 percent of global exports in 2007, according to the WTO, and should be able to offer expanded access as well.

\section{Conclusions and Recommendations}

In September 2000, the members of the United Nations General Assembly adopted the Millennium Declaration in which they pledged to "spare no effort to free our fellow men, women and children from the abject and dehumanizing conditions of extreme poverty, to which more than a billion of them are currently subjected." As part of that commitment, the General Assembly called on the industrialized countries to adopt "a policy of duty- and quota-free access for essentially all exports from the least developed countries." 34

Since then, there has been substantial progress toward that goal, but much remains to be done. In the case of the United States, which according to the analysis in this paper lags in opening its market to the poorest countries, this is an opportunity to rebuild its reputation and restore global leadership. As argued by Nancy Birdsall in a 2008 volume setting out an agenda for the next president:

[T]he single best arena for doing so may well be global development. Why? First, because working to improve people's lives everywhere so singularly reflects traditional U.S. values. And second, because global development represents, in this century as never before, clear and urgent U.S. interests. In an increasingly multipolar and interdependent world, economic growth, improved well-being, and good political relations with developing countries, where five of six people in the world live, are fundamental to

\footnotetext{
${ }^{34}$ http://www.un.org/millennium/declaration/ares552e.htm.
} 
sustaining and increasing the economic opportunities ordinary Americans enjoy and to reducing the threats they face.... ${ }^{35}$

Duty-free, quota-free market access for small and poor countries would be only one, small piece of the strategy outlined in White House and the World. But it would be far less expensive than many other policies (only the tariff revenues forgone) and acting now could give a boost to the struggling Doha Round of trade negotiations to U.S. trade and development policies, both of which have been neglected thus far by the Obama administration.

Thus, it would be useful for the United States to provide leadership, but other rich countries need to act as well. To summarize, the recommendations for global preference reform include:

- Canada, Japan, Korea should remove remaining product exclusions and the United States should adopt $100 \%$ duty-free, quota-free access for all LDCs.

- All preference-givers should reform rules of origin to make them easier to use, particularly the European Union and other Europeans with whom they coordinate trade policy; this should include extended cumulation among as broad a group as possible.

- All preference givers should making their programs for LDCs permanent (not to imply bound access for particular countries).

- Rich countries should consider expanding access to other similarly poor countries.

- Emerging economies should also expand access for LDCs and gradually move toward 100 percent coverage as well.

Adoption of these proposals would not guarantee accelerated development in the world's poorest countries. But they would create opportunities for countries to create poverty-reducing jobs, and, if coupled with domestic reforms and capacity-building and other assistance for private sector development, they could help countries reduce vulnerability to external shocks and stimulate economic growth.

\footnotetext{
${ }^{35}$ Nancy Birdsall, "Righting the Three-Legged Stool: Why Global Development Matters for Americans and What the Next President Should Do about It" in Nancy Birdsall (edit.), The White House and the World: A Global Development Agenda for the Next U.S. President, Washington: Center for Global Development, 2008, p. 32.
} 
Figure 1 Regional Trade Arrangements and LDCs

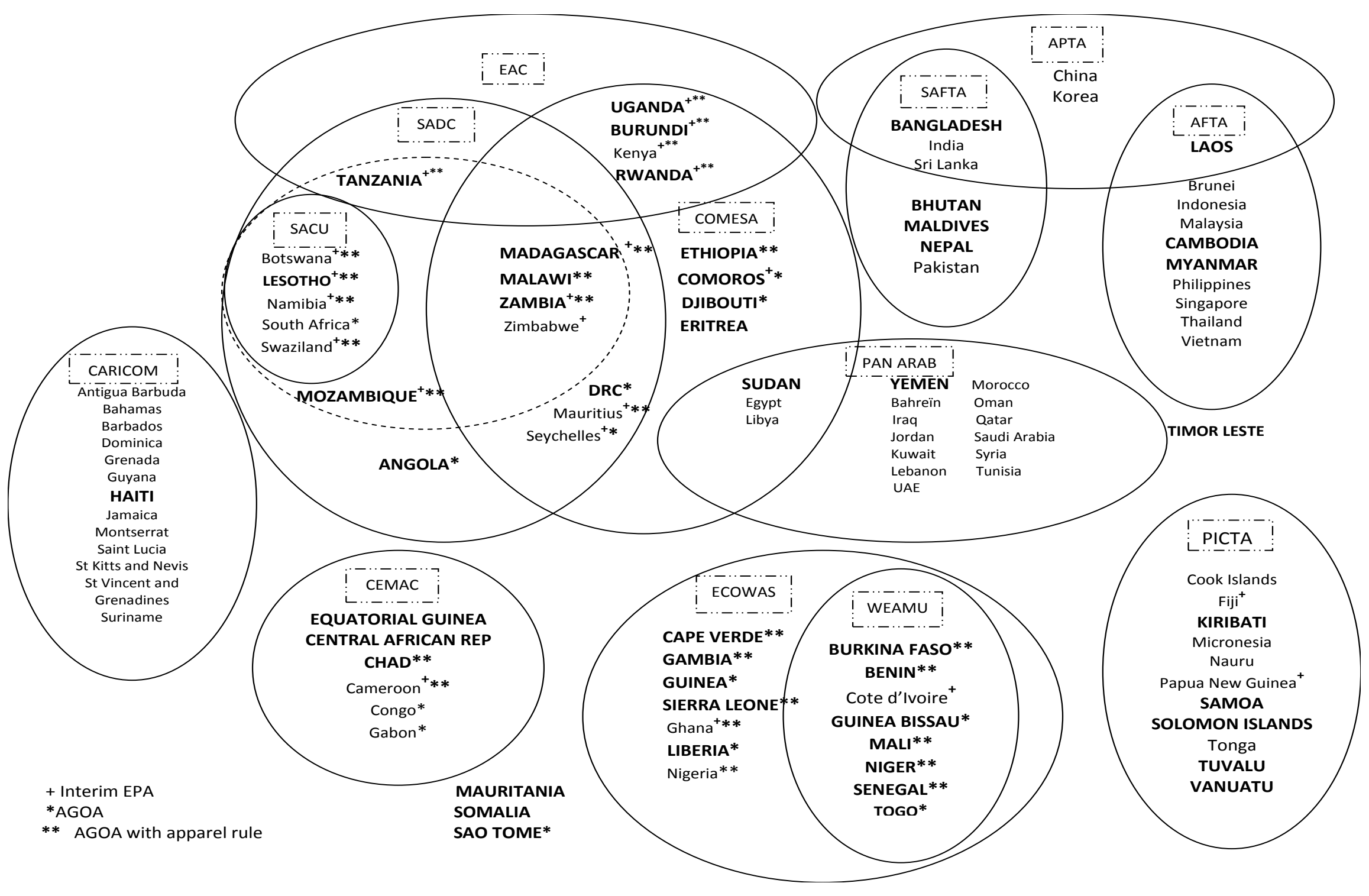



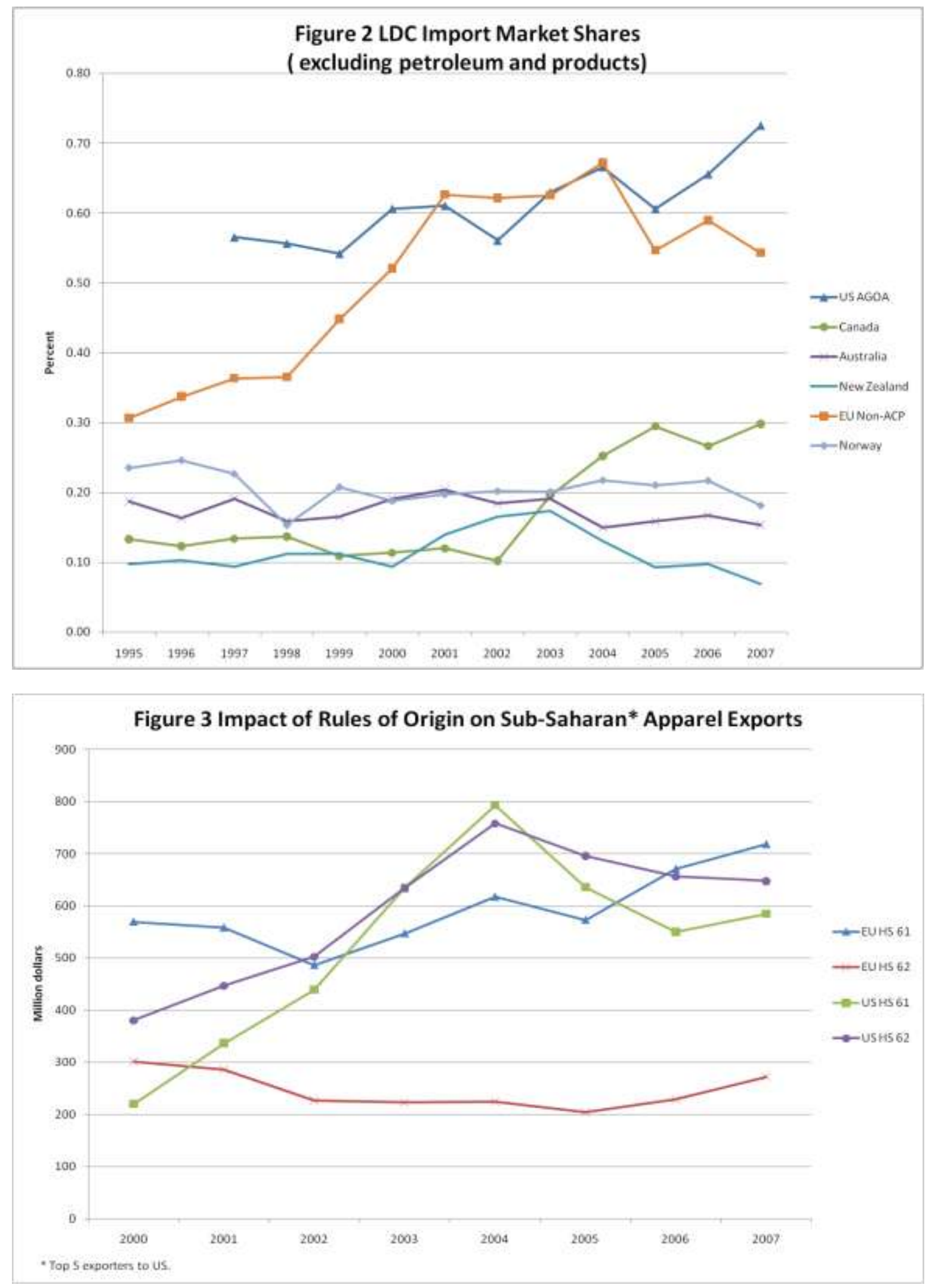

Source: UN Comtrade Database, online. 
Table 1 Average Applied Tariffs, 2005, and Tariff Peaks in Rich Countries

Average Applied Tariff*

$\begin{array}{cccc}\begin{array}{c}\text { European } \\ \text { Union }\end{array} & \text { Japan } & \begin{array}{c}\text { United } \\ \text { States }\end{array} & \text { Canada } \\ & & & \\ 13.9 & 29.3 & 2.4 & 9.0 \\ 5.1 & 9.0 & 9.6 & 8.7 \\ 1.7 & 0.4 & 0.9 & 0.9 \\ & & & \\ & & & \\ 97.7 & 85.1 & 36.6 & 27.4 \\ 0.5 & 14.7 & 57.4 & 60.1 \\ 2.8 & 0.2 & 6.0 & 11.5\end{array}$

* All partners, import-weighted.

Sources: Anderson,Martin, and van der Mensbrugghe, 2006, p. 345; UNCTAD, 2000, pp. 14-17.

Table 2 Sectoral distribution of exports by per capita income (percent)

$2005 \quad 2006 \quad 2007$

Agricultural (SITC 00-12, 21-22,

$26,29,41-43)$

$\begin{array}{lccc}\text { LICs and LDCs } & 30.9 & 28.2 & 26.6 \\ \text { Small LMICs* } & 26.8 & 25.6 & 25.6 \\ \text { UMIC } & 10.6 & 9.9 & 10.5\end{array}$

Textiles, apparel and footwear (SITC 61, 65, 83-85)

\begin{tabular}{lccc} 
LICs and LDCs & 21.0 & 21.2 & 20.9 \\
Small LMICs* & 19.3 & 13.1 & 14.4 \\
UMIC & 5.3 & 4.5 & 4.2 \\
\hline
\end{tabular}

LIC = low-income country; LDC = least-developed country;

LMIC = low middle-income country; UMIC = upper middle-income country.

* Small $=$ less than $\$ 50$ billion in gross national income, as defined by World Bank.

Source: UN Comtrade Database, online. 
Table 3 U.S. Import Duties Collected, 2008

\begin{tabular}{|c|c|c|c|c|c|}
\hline & $\begin{array}{r}\text { Total } \\
\text { imports }\end{array}$ & $\begin{array}{l}\text { Dutiable } \\
\text { imports } \\
\text { n dollars) }\end{array}$ & $\begin{array}{r}\text { Import duties } \\
\text { collected }\end{array}$ & $\begin{array}{l}\text { Duties as } \\
\text { share of } \\
\text { dutiable } \\
\text { value } \\
\text { (perc }\end{array}$ & $\begin{array}{l}\text { Duties as } \\
\text { share of } \\
\text { total value }\end{array}$ \\
\hline Cambodia & 2,410 & 2,396 & 407 & 17 & 17 \\
\hline Bangladesh & 3,745 & 3,553 & 574 & 16 & 15 \\
\hline Mongolia & 53 & 41 & 7 & 17 & 14 \\
\hline Sri Lanka & 1,958 & 1,530 & 243 & 16 & 12 \\
\hline Brunei & 121 & 106 & 13 & 12 & 11 \\
\hline Laos & 42 & 38 & 4 & 12 & 11 \\
\hline Pakistan & 3,592 & 3,127 & 358 & 11 & 10 \\
\hline Moldova & 12 & 9 & 1 & 13 & 10 \\
\hline
\end{tabular}

NB: There are countries with high average tariff rates, based on dutiable imports only, but the overall burden is less because their exports are less concentrated in the tariff peak sectors.

Source: USITC Dataweb, online. 


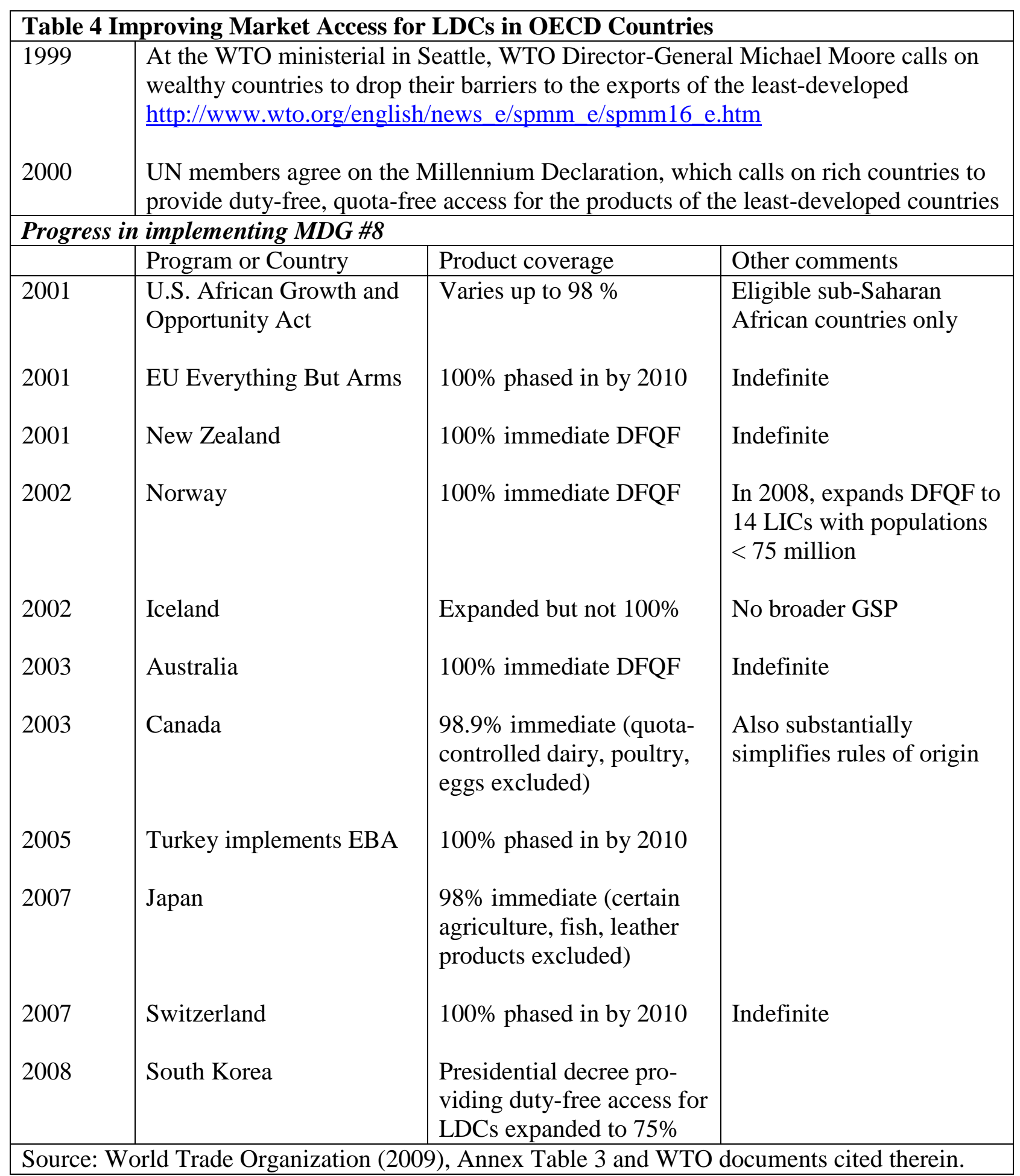




\begin{tabular}{|c|c|c|}
\hline Program & Product coverage (percent) & Other notable features \\
\hline GSP for LDCs & $\begin{array}{l}73 \% \text { of dutiable tariff lines } \\
83 \% \text { duty-free, incl. MFN }\end{array}$ & $\begin{array}{l}\text { Applies to } 12 \text { Asian LDCs, } \\
\text { excludes apparel }\end{array}$ \\
\hline $\mathrm{AGOA}$ & $\begin{array}{l}96 \% \text { of dutiable tariff lines } \\
97 \% \text { duty-free, incl.MFN } \\
84 \% \text { of dutiable tariff lines } \\
90 \% \text { duty-free, incl.MFN }\end{array}$ & $\begin{array}{l}\text { Applies to } 18 \text { African LDCs } \\
\text { that are eligible for the } \\
\text { "special apparel rule;" } \\
\text { excludes quota-controlled } \\
\text { agricultural products; textiles } \\
\text { and apparel subject to } \\
\text { restrictive rules of origin } \\
\text { outside cap in latter case } \\
\text { Applies to non-LDCs that are } \\
\text { eligible for special apparel } \\
\text { rule; excludes quota- } \\
\text { controlled agricultural } \\
\text { products. Duty-free for } \\
\text { beneficiaries not eligible for } \\
\text { special apparel rule only } \\
\sim 85 \%\end{array}$ \\
\hline HOPE Act for Haiti & $\begin{array}{l}86 \% \text { of dutiable tariff lines } \\
91 \% \text { duty-free, incl. MFN }\end{array}$ & $\begin{array}{l}\text { Subject to complex rules of } \\
\text { origin, some caps }\end{array}$ \\
\hline
\end{tabular}




\begin{tabular}{|c|c|c|c|c|c|c|}
\hline & \multicolumn{5}{|c|}{ Table 6 Assessing Key Features of Major Preference Programs for LDCs } & \multirow{3}{*}{ Korea } \\
\hline & \multirow[t]{2}{*}{ Canada } & \multirow{2}{*}{ Japan } & \multirow[t]{2}{*}{ European Union } & \multicolumn{2}{|c|}{ United States* } & \\
\hline & & & & AGOA & GSP for LDCs & \\
\hline \multirow[t]{2}{*}{$\begin{array}{l}\text { DFQF for } \\
\text { LDCs } \\
\text { product } \\
\text { coverage }\end{array}$} & $\begin{array}{l}\text { 99\%; excludes } \\
\text { quota-controlled } \\
\text { agricultural products } \\
\text { (eggs, poultry, dairy) }\end{array}$ & $\begin{array}{l}\text { 98\%; but } \\
\text { excludes rice, } \\
\text { sugar, other ag. } \\
\text { and a few other } \\
\text { products }\end{array}$ & $\begin{array}{l}100 \% \text { under } \\
\text { Everything But } \\
\text { Arms (as of end- } \\
2009 \text { ) }\end{array}$ & $\begin{array}{l}\text { 98\% duty-free for } \\
\text { eligible LDCs, } \\
\text { plus } 8 \text { others in } \\
\text { SSA (apparel not } \\
\text { quota-free) }\end{array}$ & $\begin{array}{l}\sim 83 \% \text { (excludes } \\
\text { apparel) }\end{array}$ & $75 \%$ \\
\hline & 2 & 3 & 1 & 3 & 5 & 6 \\
\hline \multirow[t]{2}{*}{$\begin{array}{l}\text { Rules of } \\
\text { origin }\end{array}$} & $\begin{array}{l}40 \% \text { valued-added } \\
\text { locally, cumulation } \\
\text { among LDCs or } \\
\text { Canada, up to } 20 \% \\
\text { may come from } \\
\text { other GSP } \\
\text { beneficiaries; for } \\
\text { apparel, value-added } \\
\text { is } 40 \%, \text { with } \\
\text { cumulation across } \\
\text { all beneficiaries } \\
\text { (incl. China) }\end{array}$ & $\begin{array}{l}\text { Change in tariff } \\
\text { heading, with } \\
\text { specific process } \\
\text { for some products } \\
\text { and cumulation } \\
\text { only with Japan } \\
\text { and a few } \\
\text { ASEAN } \\
\text { members; single } \\
\text { transformation } \\
\text { specified for } \\
\text { woven apparel }\end{array}$ & $\begin{array}{l}\text { Change in tariff } \\
\text { heading, with } \\
\text { specific processes } \\
\text { for products and } \\
\text { only limited regional } \\
\text { cumulation; yarn- } \\
\text { forward for apparel } \\
\text { (changes proposed } \\
\text { for } 2010 \text { but fate } \\
\text { unknown as of mid- } \\
\text { 2009) }\end{array}$ & $\begin{array}{l}\text { Apparel rules are } \\
\text { complex and } \\
\text { restrictive, but } \\
\text { exemptions } \\
\text { allowing fabric } \\
\text { from anywhere up } \\
\text { to a cap }\end{array}$ & $\begin{array}{l}35 \% \text { local } \\
\text { value-added } \\
\text { with limited } \\
\text { regional } \\
\text { cumulation }\end{array}$ & $\begin{array}{l}50 \% \text { local } \\
\text { value-added } \\
\text { with no } \\
\text { cumulation }\end{array}$ \\
\hline & 1 & 4 & 6 & 1 & 3 & 5 \\
\hline \multirow[t]{2}{*}{$\begin{array}{l}\text { Length of } \\
\text { program }\end{array}$} & $\begin{array}{l}\text { Renewed for } 10 \\
\text { years in } 2004\end{array}$ & $\begin{array}{l}\text { Renewed for } 10 \\
\text { years in } 2001\end{array}$ & Indefinite & $\begin{array}{l}\text { AGOA: } 2015, \\
\text { (2012 apparel rule) }\end{array}$ & Ad hoc & $\begin{array}{l}\text { By executive } \\
\text { decree }\end{array}$ \\
\hline & 2 & 2 & 1 & 4 & 5 & 6 \\
\hline $\begin{array}{l}\text { Sum of } \\
\text { rankings }\end{array}$ & 5 & 9 & 8 & 8 & 13 & 17 \\
\hline
\end{tabular}

* The other regional programs would fall somewhere in between these two on most elements. 


\begin{tabular}{|l|l|l|}
\hline \multicolumn{2}{|l}{ Table 7 Potential DFQF Beneficiaries by Per Capita Income Level, 2007 } \\
\hline & & \\
\hline Least-developed & Low-income & Low middle-income \\
\hline Afghanistan & Cote d'Ivoire* & Albania \\
\hline Angola & Ghana & Armenia \\
\hline Bangladesh & Kenya & Azerbaijan \\
\hline Benin & Kyrgystan & Bolivia* \\
\hline Bhutan & North Korea* & Cameroon \\
\hline Burkina Faso & Papua New Guinea & Congo (ROC) \\
\hline Burundi & Tajikistan* & Ecuador \\
\hline Cambodia & Uzbekistan & El Salvador** \\
\hline Cape Verde & Zimbabwe* & Georgia \\
\hline Central African Republic* & & Guatemala** \\
\hline Chad & & Guyana* \\
\hline Comoros & & Honduras** \\
\hline Congo (DROC) & & Jordan** \\
\hline Djibouti & & Kosovo \\
\hline East Timor & & Moldova \\
\hline Equatorial Guinea* & & Mongolia* \\
\hline Eritrea* & & Nicaragua** \\
\hline Ethiopia & & Paraguay \\
\hline Gambia & & Sri Lanka \\
\hline Guinea & & Swaziland* \\
\hline Guinea-Bissau & & Syria* \\
\hline Haiti & & Tonga* \\
\hline Kiribati & Tigeria & Tunisia \\
\hline Laos* & & Turkmenistan* \\
\hline Lesotho & & \\
\hline Liberia & & China* \\
\hline Madagascar & & Egypt \\
\hline Malawi & & India \\
\hline Maldives* & & Indonesia \\
\hline Mali & & Iran* \\
\hline Mauritania* & & Iraq(?) \\
\hline Mozambique & Morocco** \\
\hline Myanmar* & & Philippines \\
\hline Nepal & & Thailand \\
\hline Niger & & Ukraine \\
\hline Rwanda & & \\
\hline Samoa & & \\
\hline Sao Tome \& Principe & & billon*** \\
\hline
\end{tabular}




\begin{tabular}{|l|l|l|}
\hline Senegal & & \\
\hline Sierra Leone & & \\
\hline Solomon Islands & & \\
\hline Somalia* & & \\
\hline Sudan* & & \\
\hline Tanzania & & \\
\hline Togo & & \\
\hline Tuvalu & & \\
\hline Uganda & & \\
\hline Vanuatu & & \\
\hline Yemen & & \\
\hline Zambia & & \\
\hline
\end{tabular}

* Ineligible in the United States for either GSP and/or AGOA for political reasons.

** Have implemented FTAs with the United States.

*** Of these only Vietnam and Morocco fall between $\$ 50$ billion and $\$ 100$ billion and the others are well above $\$ 100$ billion. 